\title{
Impact of the degree of relative risk aversion, the interest rate and the exchange rate depreciation on economic welfare in a small open economy
}

\author{
Yazmín Viridiana Soriano-Morales* \\ Benjamín Vallejo-Jiménez ${ }^{* *}$ \\ Francisco Venegas-Martínez $z^{* * *}$
}

(Recibido: enero, 2017/Aceptado: abril, 2017)

\begin{abstract}
This paper is aimed at assessing the impact of the degree of relative risk aversion on economic welfare for different levels of the interest rate and the exchange rate depreciation in a small open beconomy. To do this, a representative consumer-producer makes decisions on consumption, money balances, and leisure. In order to find a closed-form solution of the household's economic welfare, it is assumed that individual's preferences belong to the family of Constant Relative Risk Aversion (CRRA) utility functions. Several comparative statics graphical experiments about the effects of the degree of relative risk aversion on economic welfare for different levels of nominal variables are carried out. Finally, we find that, under the stated assumptions, household's economic welfare seen as a function of the degree of relative risk aversion is responsive to different values of nominal variables.
\end{abstract}

Keywords: consumer-producer economics, economic welfare, degree of relative risk aversion, small open economy, interest rate, foreign exchange. JEL classification: D11, D13, D60, F41, F31, E40.

\footnotetext{
*Escuela Superior de Economía, Instituto Politécnico Nacional, <yvisoriano@gmail.com>.

** Escuela Superior de Economía, Instituto Politécnico Nacional, <matematicastotales@gmail.com>.

*** Profesor-investigador en la Escuela Superior de Economía del Instituto Politécnico Nacional. $<$ fvenegas1111@yahoo.com.mx>.
} 


\section{Impacto del grado de aversión relativa al riesgo, la tasa de interés y la tasa de depreciación del tipo de cambio en el bienestar económico en una economía pequeña y abierta}

\section{Resumen}

Esta investigación tiene como objetivo evaluar el impacto del grado de aversión relativa al riesgo en el bienestar económico para diferentes niveles de la tasa de interés y la depreciación del tipo de cambio en una economía pequeña y abierta. Para hacer esto, se supone un consumidor-productor representativo que toma decisiones de consumo, saldos monetarios y ocio. Con el fin de encontrar una solución cerrada del bienestar económico del consumidor se supone que las preferencias del individuo pertenecen a la familia de funciones de utilidad de la Aversión Relativa al Riesgo Constante (ARRC). Se realizan varios experimentos gráficos de estática comparativa sobre los efectos del grado de aversión relativa al riesgo en el bienestar económico para diferentes niveles de variables nominales. Por último, se encuentra que, de acuerdo con los supuestos establecidos, el bienestar económico del consumidor representativo visto como función del grado de aversión al riesgo relativo es sensible a diferentes valores de variables nominales.

Palabras clave: economía del consumidor-productor, bienestar económico, grado de aversión relativa al riesgo, economía pequeña y abierta, tasa de interés, tipo de cambio.

Clasificación JEL: D11, D13, D60, F41, F31, E40.

\section{Introduction}

The number of investigations dealing with the impact of nominal variables on economic welfare is large and still increasing; see, for instance: Pugsley and Rubinton (2016), Shi (2015), Soriano-Morales et al. (2015), and Kim (2003). In particular, the effects of monetary policy on economic welfare are studied in Devereux and Engel (2003), and Betts and Devereux (2000). 
It is also enough to take a look at Barro and Sala-i-Martin (1995) for an important number of references on this topic in the endogenous growth literature. ${ }^{1}$ However, in reviewing all the above specialized literature, it is still missing to assess the impact of the degree of relative risk aversion on economic welfare. This research develops a model of a small open economy populated with infinitely-lived, risk-averse, identical individuals that make decisions on consumption, real money balances, and leisure. These individuals own the firms, which produce a single perishable good with a technology having constant marginal returns. We assume that the representative individual has preferences belonging to the family of Constant Relative Risk Aversion (CRRA) utility functions. This class of felicity indexes is maybe the most widely used; see, for example: Battermann et al. (1997); Alvarez and Stokey (1998), Kamihigashi (2001), Dohmen et al. (2010), Boulier et al. (2001), Cairns et al. (2006), Deelstra et al. (2003), Moreno-Bromberg et al. (2012), Xie (2000), and Krause (2012). The main purpose of assuming that the utility function belongs to the CRRA family is to obtain a closed-form solution of the household's economic welfare.

The aim of this research is to get a closed-form solution of economic welfare related to the decision making problem of utility maximization faced by a representative rational consumer-producer with perfect foresight. Subsequently, we carry out some comparative statics experiments regarding the impact of the degree of relative risk aversion on economic welfare for different levels of nominal variables. Specifically, household's economic welfare is seen as a function of the degree of relative risk aversion and we show that economic welfare is responsive to different values of the interest rate and the exchange rate depreciation

The outline of the present research is as follows: section 2 presents the characteristics of the economy; section 3 states the household's rational behavior; section 4 describes the firm's rational behavior and the labor market equilibrium; section 5 provides a closed-form solution of household's economic welfare, and carries out some comparative statics

\footnotetext{
${ }^{1}$ A study for the Mexican case regarding the exchange rate depreciation risk and its hedging with contingent contracts can be found in González-Aréchiga et al. (2001). Another study for the Mexican economy regarding volatility issues on nominal variables is available in Venegas-Martínez and IslasCamargo (2005).
} 
exercises on exogenous variables; finally, section 6 provides conclusions and acknowledges limitations.

\section{Characteristics of the economy}

Consider a small open economy with the following characteristics. Consumers and firms are assumed to be identical, which allows us to assume a representative individual that maximizes his satisfaction and profits. Moreover, the economy produces and consumes a unique internationally traded good, which is, for the sake of simplicity, free of barriers to trade. It is also assumed that producers share the same technology, which has constant returns to scale.

It is suppose that the purchasing power parity (PPP) holds, that is, $P_{t}=P_{t}^{*} E_{t}$, where $P_{t}$ is the general price level of the domestic economy, $P_{t}^{*}$ is the general price level of the foreign economy, and $E_{t}$ is the nominal exchange rate. From this assumption, we can obtain the instantaneous percentage changes of all variables involved in the PPP condition, namely, $\dot{P}_{t} / P_{t}=\pi, \dot{P}_{t}^{*} / P_{t}^{*}=\pi^{*}$ and $\dot{E}_{t} / E_{t}=\varepsilon$, where $p$ is the inflation rate in the domestic economy, $p^{*}$ is the inflation rate of the foreign economy, and $e$ is the actual rate of exchange depreciation, which under perfect foresight it is also equals to the anticipated rate of exchange depreciation. Therefore, from the PPP relationship, it readily follows that.

$$
\pi=\pi^{*}+\varepsilon
$$

Moreover, under perfect foresight, the uncovered interest rate parity (UIP) relationship is given by.

$$
r=i-\pi
$$

where $r$ is the domestic real interest rate and $i$ is the domestic nominal interest rate. In virtue that we have a small economy, it can be written $r=r^{*}$ where $r^{*}$ stands for the foreign interest rate. It will be assumed that $P_{t}^{*}$ is constant and equal to unity, that is, $P_{t}^{*}=1$, this implies $p^{*}=0$, therefore, we have $p=e$ Hence, by substituting (1) into (2), it follows.

$$
r^{*}=i-\varepsilon .
$$




\section{Household's rational behavior}

In this section, we state the features of the representative household. First, the individual demands real money balances.

$$
m_{t}^{d}=M_{t} / P_{t}
$$

and also maintains real bonds, $b_{t}=B_{t} / P_{t}$, which are internationally traded (with perfect capital mobility). Here, $M_{t}$ is the nominal stock of money held by the individual, and $B_{t}$ is the nominal price of the asset. We assume that the bonds pay the real interest rate $r^{*}$ The consumer gets income from labor given by $w n_{t}^{s}$ where $n_{t}^{s}$ is the number of hours that he devotes to work, and $w$ is real wage per unit of time. The individual is also a producer owning his firm and getting a profit $\Pi_{t}$. Therefore, the consumer's budget constraint becomes:

$$
\dot{m}_{t}^{d}+\dot{b}_{t}=r^{*} b_{t}-\pi m_{t}^{d}+w n_{t}^{s}-c_{t}+\Pi_{t}
$$

The representative rational consumer wishes to maximize his/her total discounted utility from consumption, $c_{t}$, real monetary balances $m_{t}$, and leisure $l_{t}^{d}=1-n_{t}^{s}$. It is worth mentioning that the number of total available hours of the individual has been restricted to unity. The agent wishes to maximize his/her total discounted utility. ${ }^{2}$

$$
\int_{0}^{\infty} u\left(c_{t}, m_{t}, l_{t}^{d}\right) e^{-\rho t} \mathrm{~d} t
$$

where $u=u\left(c_{t}, m_{t}^{d}, l_{t}^{d}\right)$ is the satisfaction index. Therefore, the representative individual wishes to solve the following intertemporal optimization problem.

subject to

$$
\text { Maximize } \int_{0}^{\infty} u\left(c_{t}, m_{t}^{d}, l_{t}^{d}\right) e^{-\rho t} \mathrm{~d} t
$$

$$
\dot{m}_{t}^{d}+\dot{b}_{t}=r^{*} b_{t}-\pi m_{t}^{d}+w n_{t}^{s}-c_{t}+\Pi_{t}
$$

where $r$ is the subjective discount rate (this parameter measures how anxious or compulsive is the individual for consuming). We suppose that $m_{0}^{d}$ and $b_{0}$ are both given and known. From now on, for the sake of simplicity, it will

2 A stochastic set up of this utility maximization problem can be found in Venegas-Martínez (2000), (2005), (2006) and (2009), and Venegas-Martínez and González-Aréchiga (2000). 
be assumed that the subjective discount rate is equal to the real interest rate, that is, $r=r^{*}$. It is worth noticing that the assumption of this equality means that it is just attained by coincidence since $r$ is an intertemporal preference parameter and $r^{*}$ is the international price of the bond market. Also, for the time being, it will be assumed that profit $\Pi_{t}=0$; this fact will be justified later on. From the above assumptions, the budget constraint becomes.

$$
\dot{m}_{t}^{d}+\dot{b}_{t}=r^{*} b_{t}-\pi m_{t}^{d}+w n_{t}^{s}-c_{t} .
$$

The above equation can be rewritten, in a present value form, in the following way:

$$
b_{0}=\int_{0}^{\infty}\left(c_{t}+\dot{m}_{t}^{d}+\pi m_{t}^{d}-w n_{t}^{s}\right) e^{-r^{*} t} \mathrm{~d} t
$$

The Lagrangian, $L\left(c_{t}, m_{t}, l_{t}^{d}, \lambda\right)$, associated with maximizing (7) subject to (9) is given by.

$$
L=\left(\mathrm{u}_{0}\left(c_{t}\right)+\varphi_{1} \mathrm{u}_{1}\left(m_{t}^{d}\right)+\varphi_{2} \mathrm{u}_{2}\left(1-n_{t}^{s}\right)\right) e^{-r^{*} t}-\lambda e^{-r^{*} t}\left(c_{t}+\dot{m}_{t}^{d}+\pi m_{t}^{d}-w n_{t}^{s}\right)
$$

with

$$
\mathrm{u}_{i}(x)= \begin{cases}\frac{x^{1-\eta_{i}}}{1-\eta_{i}}, & \eta_{i} \neq 1, \\ \ln (x), & \eta_{i}=1 .\end{cases}
$$

and where $h_{i}$ for $i \in 0,1,2$ are constants (the degrees of relative risk aversion), and $l$ is the Lagrange multiplier. The first-order conditions (necessary conditions) for an interior solution of the utility maximization problem are given by:

$$
\frac{\partial L}{\partial c_{t}}=0, \frac{\partial L}{\partial m_{t}^{d}}-\frac{\mathrm{d}}{\mathrm{d} t}\left(\frac{\partial L}{\partial \dot{m}_{t}^{d}}\right)=0, \text { and } \frac{\partial L}{\partial l_{t}^{d}}=0
$$

The above second equation is known as the Euler-Lagrange equation. After computing the partial derivatives, it is obtained that.

$$
\begin{gathered}
c_{t}=\lambda^{-\frac{1}{\eta_{0}}}, \\
m_{t}^{d}=\left(\frac{\varphi_{1}}{\lambda\left(r^{*}+\varepsilon\right)}\right)^{\frac{1}{\eta_{1}}}=\text { constant, }
\end{gathered}
$$




$$
\begin{gathered}
\dot{m}_{t}^{d}=0 \\
n_{t}^{s}=1-\left(\frac{\varphi_{2}}{\lambda w}\right)^{\frac{1}{\eta_{2}}}
\end{gathered}
$$

In order to determine $l$, equations (11)-(14) are substituted in constraint (9), so.

$$
\begin{aligned}
b_{0} & =\int_{0}^{\infty}\left(\left(\frac{1}{\lambda}\right)^{\frac{1}{\eta_{0}}}+\pi\left(\frac{\varphi_{1}}{\lambda\left(r^{*}+\varepsilon\right)}\right)^{\frac{1}{\eta_{1}}}-w+w^{\frac{\eta_{2}-1}{\eta_{2}}}\left(\frac{\varphi_{2}}{\lambda}\right)^{\frac{1}{\eta_{2}}}\right) e^{-r^{*} t} \mathrm{~d} t \\
& =\frac{1}{r^{*}}\left(\left(\frac{1}{\lambda}\right)^{\frac{1}{\eta_{0}}}+\pi\left(\frac{\varphi_{1}}{\lambda\left(r^{*}+\varepsilon\right)}\right)^{\frac{1}{\eta_{1}}}-w+w^{\frac{\eta_{2}-1}{\eta_{2}}}\left(\frac{\varphi_{2}}{\lambda}\right)^{\frac{1}{\eta_{2}}}\right)
\end{aligned}
$$

For the sake of simplicity, in what follows, it will be assumed that $\eta_{0}=\eta_{1}=\eta_{2}=\eta$, which implies.

$$
\lambda=\frac{1+\pi\left(\frac{\varphi_{1}}{r^{*}+\varepsilon}\right)^{\frac{1}{\eta}}+w^{\frac{\eta-1}{\eta}} \varphi_{2}^{\frac{1}{\eta}}}{r^{*} b_{0}+w}
$$

\section{Firms rational behavior and labor market equilibrium}

The main characteristic of the representative firm are the following: it is supposed that the firm's production function uses only labor and has constant marginal returns.

$$
f\left(n_{t}^{d}\right)=A n_{t}^{d}
$$

where $A$ is a constant standing for the marginal product of labor. The firm wishes to maximize its profit.

$$
\Pi_{t}=f\left(n_{t}^{d}\right)-w n_{t}^{d}
$$

The necessary condition for a maximum is given by $w=A$. This also leads to $\Pi_{t}=0$. Therefore, equilibrium in the market labor leads to. 


$$
n_{t}=1-\left(\frac{\varphi_{2}\left(r^{*} b_{0}+A\right)}{A\left(1+\pi\left(\frac{\varphi_{1}}{r^{*}+\varepsilon}\right)^{\frac{1}{\eta}}+A^{\frac{\eta-1}{\eta}} \varphi_{2}^{\frac{1}{\eta}}\right)}\right)^{\frac{1}{\eta}}
$$

\section{Household's economic welfare}

The household's economic welfare (indirect utility), $W_{h}$, is obtained by substituting the optimal decisions given in (11), (12) and (14) in the direct utility stated in (6), for $h=1$, we have.

$$
W_{\eta=1}=\int_{0}^{\infty}\left(\ln \left(\frac{\left(r^{*} b_{0}+w\right)}{\left(1+\frac{\pi \varphi_{1}}{\left(r^{*}+\varepsilon\right)}+\varphi_{2}\right)}\right)+\varphi_{1} \ln \left(\frac{\left(r^{*} b_{0}+w\right) \varphi_{1}}{\left(1+\frac{\pi \varphi_{1}}{\left(r^{*}+\varepsilon\right)}+\varphi_{2}\right)\left(r^{*}+\varepsilon\right)}\right)+\varphi_{2} \ln \left(\frac{\varphi_{2}\left(r^{*} b_{0}+A\right)}{A\left(1+\frac{\pi \varphi_{1}}{r^{*}+\varepsilon}+\varphi_{2}\right)}\right)\right) e^{-r^{*} t} \mathrm{~d} t
$$

By using the result $\int_{0}^{\infty} r^{*} e^{-r^{*} t} \mathrm{~d} t=1$ in the above integral, it follows that

$$
\begin{aligned}
& W_{\eta=1}=\frac{1}{r^{*}}\left(\ln \left(\frac{\left(r^{*} b_{0}+w\right)}{\left(1+\frac{\pi \varphi_{1}}{\left(r^{*}+\varepsilon\right)}+\varphi_{2}\right)}\right)+\varphi_{1} \ln \left(\frac{\varphi_{1}\left(r^{*} b_{0}+w\right)}{\left(1+\frac{\pi \varphi_{1}}{\left(r^{*}+\varepsilon\right)}+\varphi_{2}\right)\left(r^{*}+\varepsilon\right)}\right)+\varphi_{2} \ln \left(\frac{\varphi_{2}\left(r^{*} b_{0}+A\right)}{A\left(1+\frac{\pi \varphi_{1}}{r^{*}+\varepsilon}+\varphi_{2}\right)}\right)\right) \\
& W_{\eta=1}=\frac{1}{r^{*}}\left\{\ln \left(r^{*} b_{0}+w\right)-\ln \left(1+\frac{\pi \varphi_{1}}{\left(r^{*}+\varepsilon\right)}+\varphi_{2}\right)+\varphi_{1}\left(\ln \left(r^{*} b_{0}+w\right)-\ln \left(1+\frac{\pi \varphi_{1}}{\left(r^{*}+\varepsilon\right)}+\varphi_{2}\right)\left(r^{*}+\varepsilon\right)\right)\right. \\
& \left.+\varphi_{2}\left(\ln \left(\varphi_{2}\left(r^{*} b_{0}+A\right)\right)-\ln \left(A\left(1+\frac{\pi \varphi_{1}}{r^{*}+\varepsilon}+\varphi_{2}\right)\right)\right)\right\}
\end{aligned}
$$

Observe that economic welfare depends on the exchange rate depreciation, the interest rate, preference parameters, and initial endowments. For $\eta \neq 1$, we have.

$$
W_{\eta \neq 1}=\int_{0}^{\infty}\left(\frac{c_{t}^{1-\eta}}{1-\eta}+\varphi_{1} \frac{\left(m_{t}^{d}\right)^{1-\eta}}{1-\eta}+\varphi_{2} \frac{\left(l_{t}^{d}\right)^{1-\eta}}{1-\eta}\right) e^{-r^{+} t} \mathrm{~d} t
$$




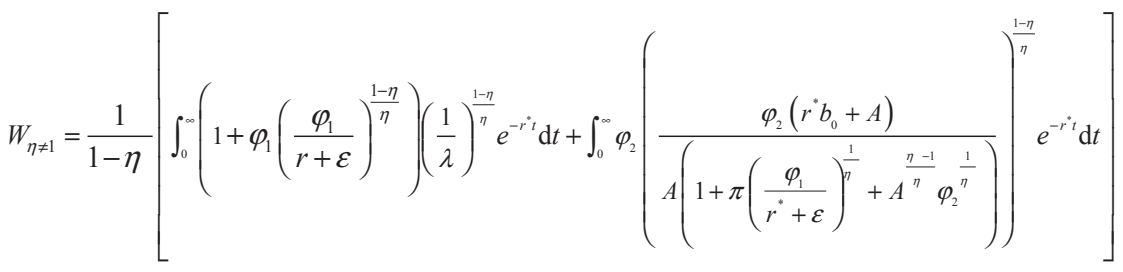

$$
\begin{aligned}
& W_{\eta \neq 1}=\frac{1}{(1-\eta) r^{*}}\left[\left(1+\varphi_{1}\left(\frac{\varphi_{1}}{r+\varepsilon}\right)^{\frac{1-\eta}{\eta}}\right)\left(\frac{1}{\lambda}\right)^{\frac{1-\eta}{\eta}}+\varphi_{2}\left(\frac{\varphi_{2}\left(r^{*} b_{0}+A\right)}{A\left(1+\pi\left(\frac{\varphi_{1}}{r^{*}+\varepsilon}\right)^{\frac{1}{\eta}}+A^{\frac{\eta-1}{\eta}} \varphi_{2}^{\frac{1}{\eta}}\right)}\right]\right. \\
& W_{\eta \neq 1}=\frac{1}{(1-\eta) r^{*}}\left[\begin{array}{l}
\left(1+\varphi_{1}\left(\frac{\varphi_{1}}{r+\varepsilon}\right)^{\frac{1-\eta}{\eta}}\left(\frac{r^{*} b_{0}+w}{1+\pi\left(\frac{\varphi_{1}}{r^{*}+\varepsilon}\right)^{\frac{1}{\eta}}+w^{\frac{\eta-1}{\eta}} \varphi_{2}^{\frac{1}{\eta}}}\right)^{\frac{1-\eta}{\eta}}\right. \\
+\varphi_{2}\left(\frac{\varphi_{2}\left(r^{*} b_{0}+A\right)}{A\left(1+\pi\left(\frac{\varphi_{1}}{r^{*}+\varepsilon}\right)^{\frac{1}{\eta}}+A^{\frac{\eta-1}{\eta}} \varphi_{2}^{\frac{1}{\eta}}\right)}\right)
\end{array}\right]
\end{aligned}
$$

\subsection{Comparative statics}

In this section, we carry out some comparative statics graphical experiments about the effects of the degree of relative risk aversion on economic welfare for different values of nominal variables. In order to compute economic welfare, we establish the following parameter values: $A=1, b_{0}=1, p=0.04$, $e=0.04, j_{1}=1, j_{2}=1$, and $w=1$. If $r^{*} \in(0,1]$. In this case, we have.

$$
\begin{aligned}
& \frac{\partial W}{\partial r^{*}}<0 \quad \text { for } \quad \eta \in(0.5,1) \\
& \frac{\partial W}{\partial r^{*}} \geq 0 \quad \text { for } \quad \eta \geq 1 \\
& \frac{\partial W}{\partial r^{*}}<0 \quad \text { for } \quad \eta<-0.2
\end{aligned}
$$


The behavior of $y=\frac{\partial W}{\partial r^{*}}$ as a function of the relative risk aversion parameter, $h$, with several values of the interest rate $r^{*}$ is shown in the charts of figure 1 (see Appendix A for the explicit partial derivative of y with respect $r$ ).

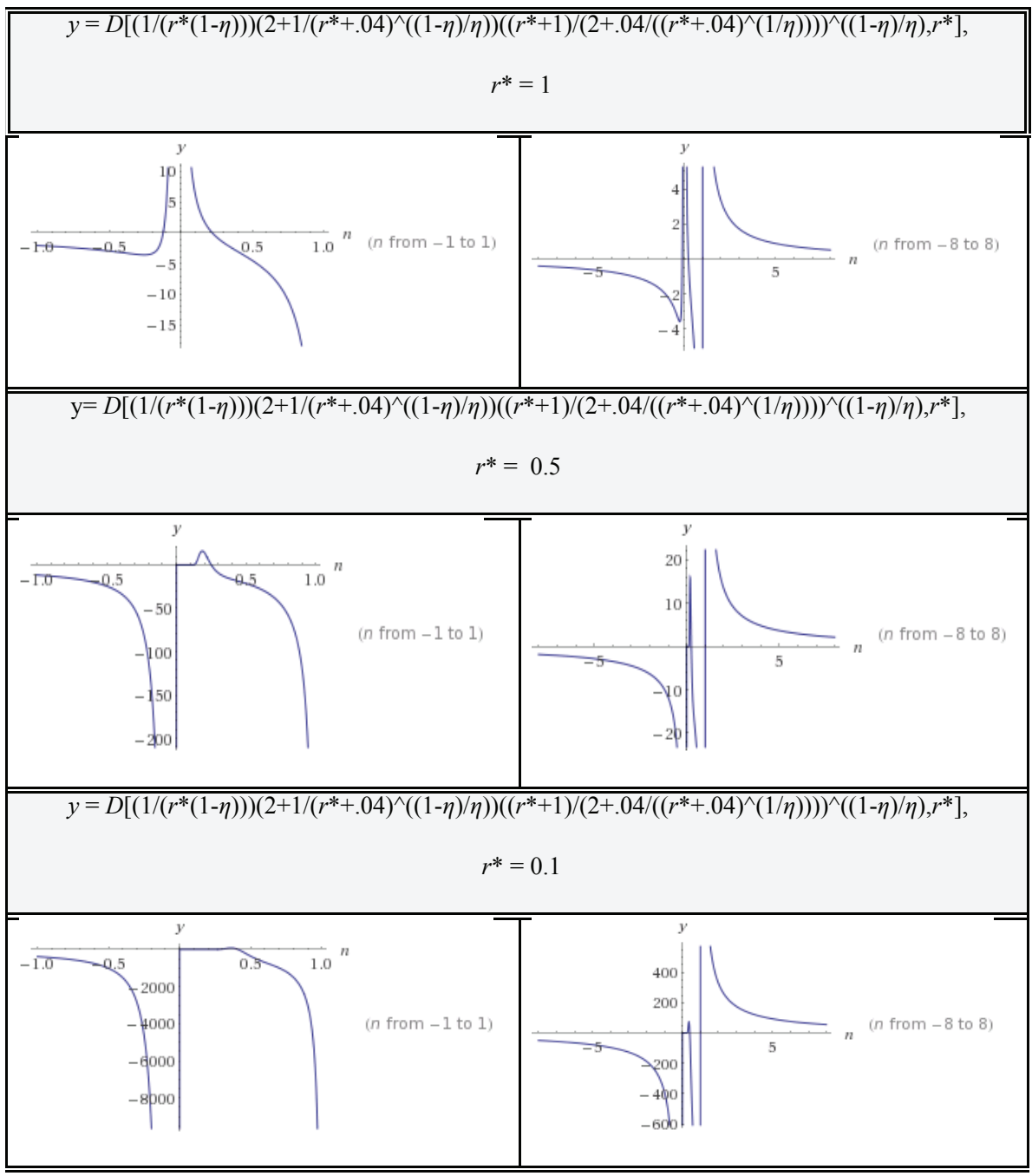


IMPACT OF THE DEGREE OF RELATIVE RISK AVERSION, THE INTEREST RATE AND THE EXCHANGE RATE DEPRECIATION ON ECONOMIC WELFARE IN A SMALL OPEN ECONOMY

\section{Figure 1. Conclusion.}

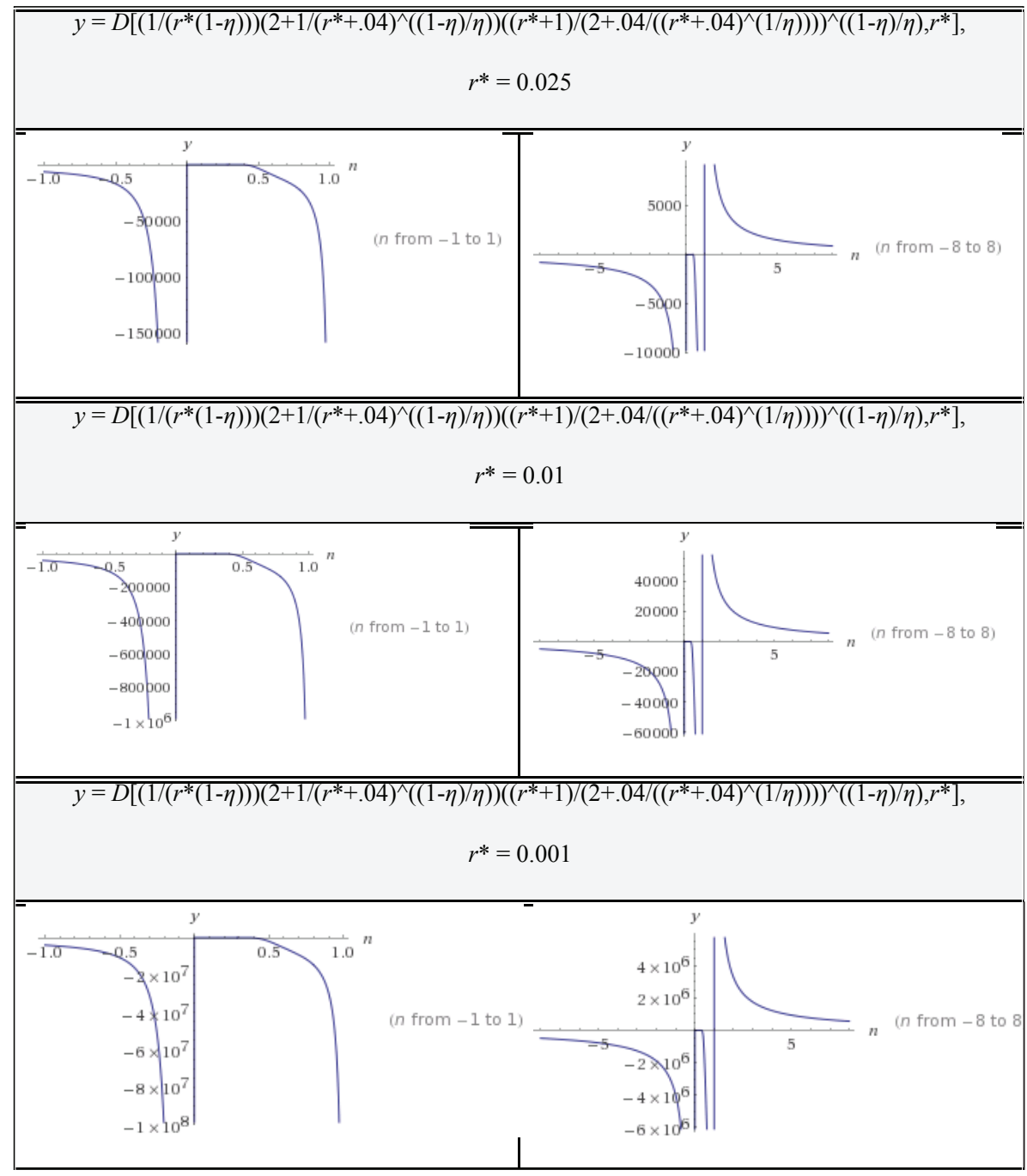

Source: Author's own elaboration with Wolfram Alpha.

Figure 1

Comparative statics graphical experiments of welfare as a function of with respect to different values of the interest rate 
The above charts show that $y=\frac{\partial W}{\partial r^{*}}$ has an asymptotic behavior on both sides of the horizontal axis at $y=0$, for $h<-0.2$ and $h<1$. It can be seen that for a fixed $r^{*} \in(0,1]: \frac{\partial W}{\partial r^{*}}<0$ for $\eta \in(0.5,1), \frac{\partial W}{\partial r^{*}} \geq 0$ for $\eta \geq 1$, and $\frac{\partial W}{\partial r^{*}}<0$ for $h<-0.2$.

Now, let us consider the parameter values $A=1, b_{0}=1, r^{*}=0.25, j_{1}=1, j_{2}=1$, $w=1$, solving for $r$ and a fixed $\varepsilon \in(0,1]$, we have.

$$
\begin{array}{lll}
\frac{\partial W}{\partial \varepsilon}<0 & \text { For } & \\
\frac{\partial W}{\partial \varepsilon} \geq 0 & \text { For } & \eta<0
\end{array}
$$

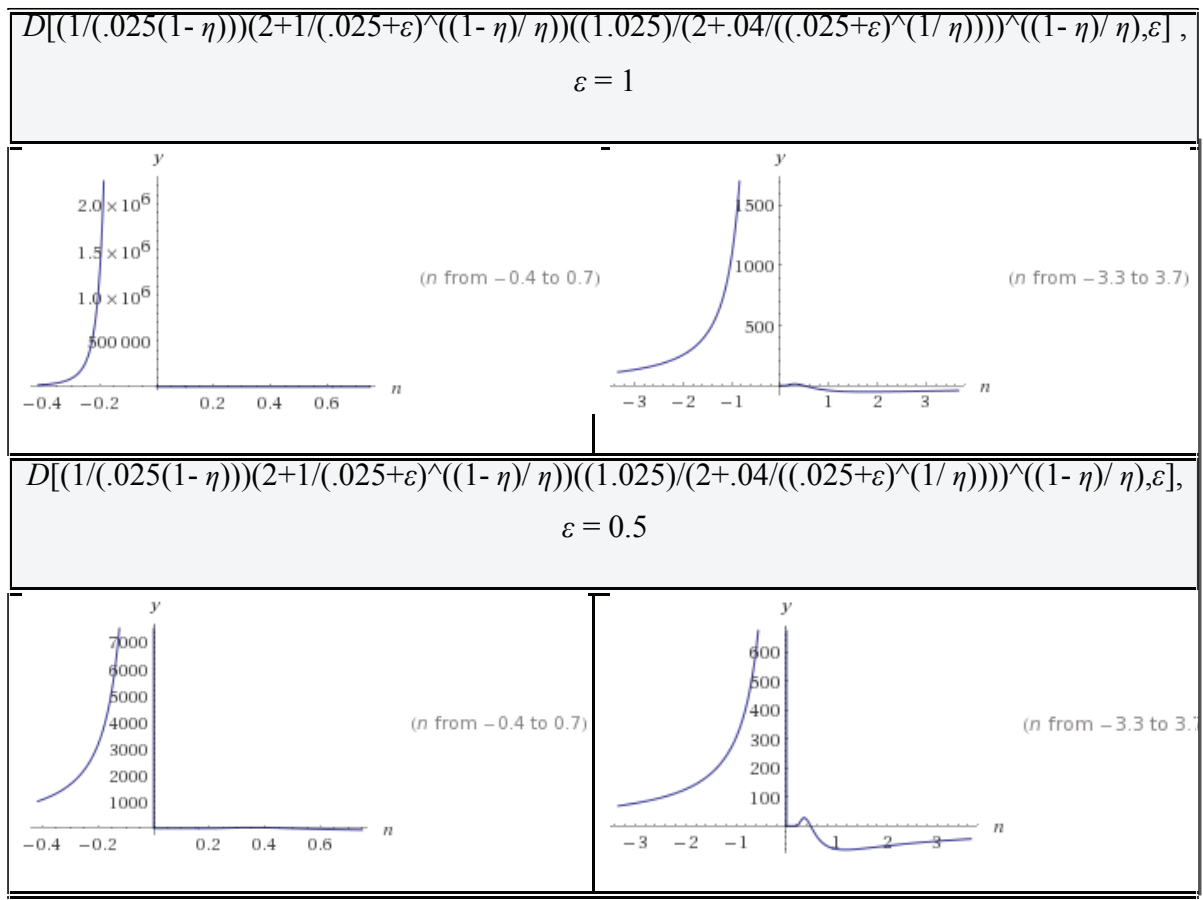


Figure 2. Conclusion.

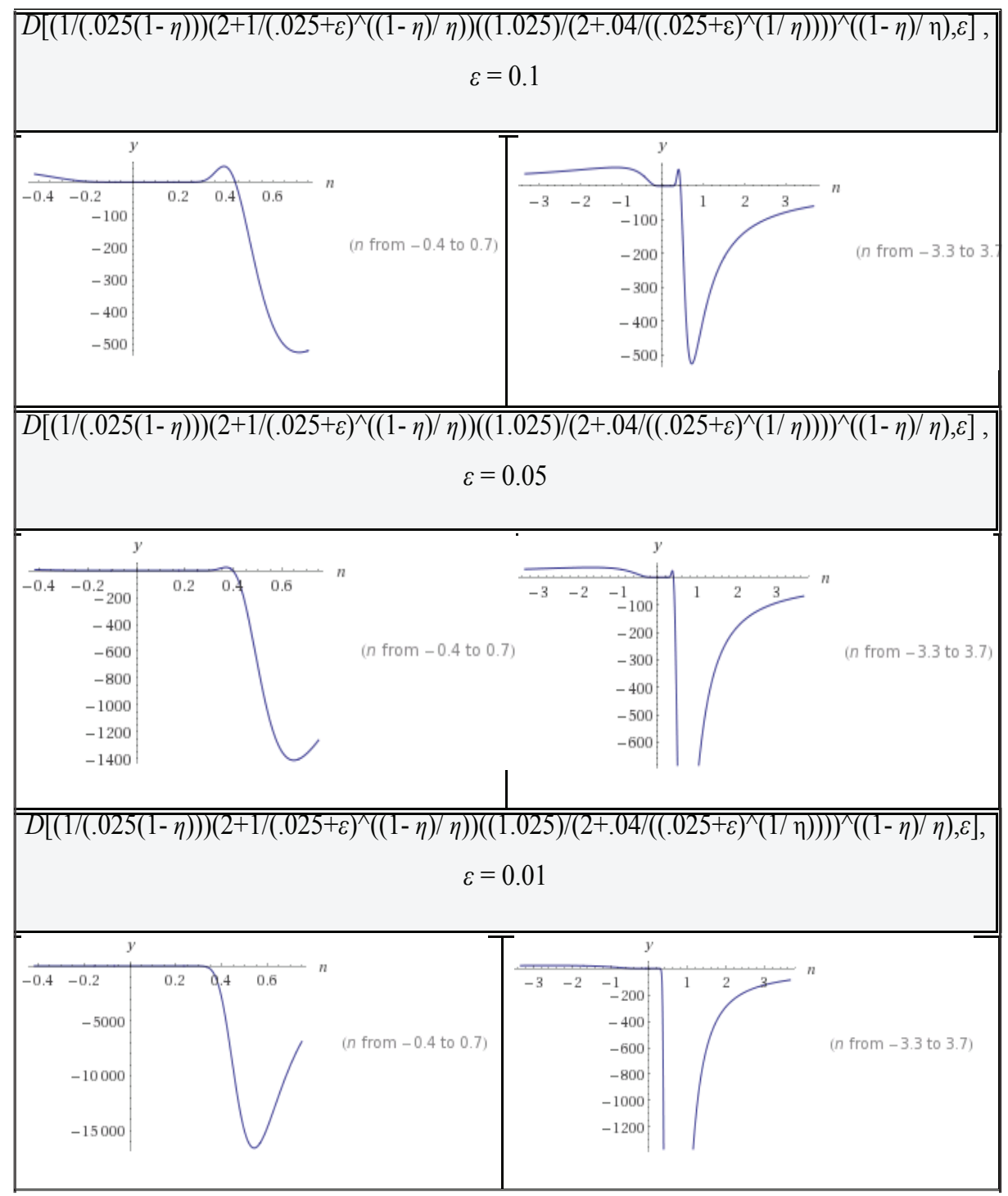

Source: author's own elaboration with Wolfram Alpha.

Figure 2

Comparative statics graphical experiments of welfare as a function of with respect to different values of the exchange rate depreciation 
The behavior of $y=\frac{\partial W}{\partial \varepsilon}$ as function of the relative risk aversion parameters, $h$, for different values of $e$ is shown in the charts of figure 2 (see Appendix $B$ for the complete partial derivative of $\mathrm{y}$ with respect $e$ ).

The above charts show that $y=\frac{\partial W}{\partial \varepsilon}$ has an asymptotic behavior on the right side of the horizontal axis at $y=0$ for $h>1$. Moreover, it can be seen that for each fixed $\varepsilon \in(0,1], \frac{\partial W}{\partial \varepsilon}<0$ for $\eta \geq 1$, and $\frac{\partial W}{\partial \varepsilon} \geq 0$ for $h<0$.

Notice also that $\frac{\partial W}{\partial b_{0}}>0$ for all $h<0$, while $\frac{\partial W}{\partial b_{0}}>0$ for all $h<0$. Finally, observe that household's economic welfare, in a small open economy (price-taker), as function of the degree of relative risk aversion, $h$, is responsive to the values of the interest rate and the exchange rate depreciation particularly for small values of the deep parameter $h$.

\section{Conclusion}

In this research, within a small open economy framework, it was obtained a closed form solution of welfare economics as a function of the degree of relative risk aversion. To do this, we assumed identical rational individuals with preferences belonging to the CRRA family of utility functions. Several comparative statics experiments about the effects of the degree of relative risk aversion on economic welfare for different levels of nominal variables were carried out. Finally, we remark that economic welfare seen as a function of the degree of relative risk aversion is responsive to different values of the interest rate and the exchange rate depreciation. Needless to say, more research has to be done to include the stochastic behavior of the interest rate and the exchange rate depreciation by modeling with dynamics driven by mixed jump-diffusion processes modulated by a Markov chain (Markov regime switching). 


\section{References}

Barro, R. and X. Sala-i-Martin (1995). Economic Growth. Mc. McGraw-Hill, New York, pp. 240-266.

Battermann, H.; U. Broll and J. Wahl (1997). "Constant Relative Risk Aversion and Form Equivalence Classes". Working Paper Series II, No. 345, pp. 219-145.

Betts, C. and M. B. Devereux (2000). “Exchange Rate Dynamics in a Model of Pricingto-Market". Journal of International Economics, vol. 50, No. 1, pp. 215-244.

Boulier, J.; S. Huang and G.; Taillard (2001). “Optimal Management under Stochastic Interest Rates: the Case of a Protected Defined Contribution Pension Fund". Insurance: Mathematics and Economics, vol. 28, No. 2, pp. 173-189.

Cairns, A., D. Blake and K. Dowd (2006). "Stochastic Life styling: Optimal dynamic asset allocation for defined-contribution pension plans", Journal of Economic Dynamic and Control, vol. 30, No. 5, pp. 843-877.

Deelstra, G., M. Grasselli and P. Koehl (2003). “Optimal Investment Strategies in the Presence of a Minimum Guarantee". Insurance: Mathematics and Economics, vol. 33, No. 1, pp. 189-207.

Devereux, M. B. and C. Engel (2003). "Monetary Policy in the Open Economy Revisited: Price Setting and Exchange-Rate Flexibility". Review of Economic Studies, vol. 70, No. 4, pp. 765-783.

Dohmen, T.; A. Falk, D. Huffman and U. Sunde (2010). "Are Risk Aversion and Patience Related to Cognitive Ability?" American Economic Review, vol. 100, pp. 1238-1260.

Gao, J. (2008). “Stochastic Optimal Control of DC Pension Funds”. Insurance: Mathematics and Economics, vol. 42, No. 3, pp. 1159-1164.

González-Aréchiga, B.; J. Díaz-Tinoco y F. Venegas-Martínez (2001). “Riesgo cambiario, brecha de madurez y cobertura con futuros: análisis local y de valor en riesgo". Economía Mexicana, Nueva Época, vol. 10, No. 2, pp. 259-290.

Kim, J. (2003). "Welfare Evaluation of Monetary Policy Rules in a Model with Nominal Rigidities". Federal Reserve Bank of Minneapolis. Working Paper. Retrievable from: https://www.mpls.frb.org/ /media/files/pubs/bankingpolicy/papers/wp3-03.pdf.

Krause, A. (2012). “Optimal Saving Taxation when Individuals have Different CRRA Utility Functions". Annals of Economics and Statistics. No. 113-114, pp. 207.

Moreno-Bromberg, S.; T. Pirvu and A. Réveillac (2012). CRRA Utility Maximization under Risk Constraints. arXiv preprint arXiv: 1106.1702. 
Pugsley, B. and H. Rubinton (2016). "Inequality in the Welfare Costs of Disinflation. Princeton University". Working Paper. Retrievable from: https://www. newyorkfed.org/medialibrary/media/research/economists/pugsley/mpinequality_ april2016.pdf?la=en.

Shi, J. (2015). "The Short Run Welfare Implications of Openness to FDI and Monetary Policy. Peking University", Working Paper. Retrievable from: https:// www.nottingham.ac.uk/gep/documents/conferences/2015-16/china/shi.pdf.

Soriano-Morales, Y. V.; F. Venegas-Martínez y B. Vallejo-Jiménez (2015). “Determination of the Equilibrium Expansion Rate of Money when Money Supply is driven by a Time-homogeneous Markov Modulated Jump Diffusion Process". Economics Bulletin, vol. 35, No. 4, pp. 2074-2084.

Venegas-Martínez, F. y A. Islas Camargo (2005). "Volatilidad en los mercados de América Latina. Efectos de Largo plazo". Comercio Exterior, vol. 55, núm. 11, pp. 936-947.

Venegas-Martínez, F. (2000). “On Consumption, Investment”, and Risk. Economía Mexicana, Nueva Época, vol. 9, No. 2, pp. 227-244.

Venegas-Martínez, F. (2005). "Política fiscal, estabilización de precios y mercados incompletos". Estudios Económicos, vol. 20, núm. 1, pp. 3-18.

Venegas-Martínez, F. (2006). "Fiscal Policy in a Stochastic Temporary Stabilization Model: Undiversifiable Devaluation Risk". Journal of World Economic Review, vol. 1, No. 1, pp. 87-106.

Venegas-Martínez, F. (2009). “Temporary Stabilization in Developing Countries and Real Options on Consumption". International Journal of Economic Research, vol. 6, No. 2, pp. 237-257.

Venegas-Martínez, F. y B. González-Aréchiga (2000). “Mercados financieros incompletos y su impacto en los programas de estabilización de precios: el caso mexicano". Momento Económico, núm. 111, pp. 20-27.

Vigna, E. (2009). "Mean-variance Inefficiency of CRRA and CARA Utility Function for Portfolio Selection in Defined Contribution Pension Schemes". Working Paper No. 108.

Xie, D. (2000). "Power Risk Aversion Utility Functions". Annals of Economics and Finance, vol. 1, No. 2, pp. 265-282. 
Appendix A. Partial derivative of $W$ with respect to $r^{*}$

$$
\begin{aligned}
& \frac{\partial W_{\eta \neq 1}}{\partial r^{*}}=\frac{-1}{(1-\eta) r^{* 2}}\left[\begin{array}{l}
\left(1+\varphi_{1}\left(\frac{\varphi_{1}}{r+\varepsilon}\right)^{\frac{1-\eta}{\eta}}\right)\left(\frac{r^{*} b_{0}+w}{1+\pi\left(\frac{\varphi_{1}}{r^{*}+\varepsilon}\right)^{\frac{1}{\eta}}+w^{\frac{\eta-1}{\eta}} \varphi_{2}^{\frac{1}{\eta}}}\right)^{\frac{1-\eta}{\eta}} \\
+\varphi_{2}\left(\frac{\varphi_{2}\left(r^{*} b_{0}+A\right)}{A\left(1+\pi\left(\frac{\varphi_{1}}{r^{*}+\varepsilon}\right)^{\frac{1}{\eta}}+A^{\frac{\eta-1}{\eta}} \varphi_{2}^{\frac{1}{\eta}}\right.}\right)
\end{array}\right] \\
& {\left[\left(1+\left(\frac{\eta-1}{\eta}\right) \varphi_{1}^{\frac{1}{\eta}}(r+\varepsilon)^{-\frac{1}{\eta}}\right)\left(\frac{r^{*} b_{0}+w}{1+\pi\left(\frac{\varphi_{1}}{r^{*}+\varepsilon}\right)^{\frac{1}{\eta}}+w^{\frac{\eta-1}{\eta}} \varphi_{2}^{\frac{1}{\eta}}}\right)^{\frac{1-\eta}{\eta}}\right.} \\
& +\frac{1}{(1-\eta) r^{*}}+\left(\frac{1-\eta}{\eta}\right)\left(1+\varphi_{1}\left(\frac{\varphi_{1}}{r+\varepsilon}\right)^{\frac{1-\eta}{\eta}}\right)\left(\frac{r^{*} b_{0}+w}{1+\pi\left(\frac{\varphi_{1}}{r^{*}+\varepsilon}\right)^{\frac{1}{\eta}}+w^{\frac{\eta-1}{\eta}} \varphi_{2}^{\frac{1}{\eta}}}\right)^{\frac{1-2 \eta}{\eta}}\left(\begin{array}{c}
b_{0}\left(1+\pi\left(\frac{\varphi_{1}}{r^{*}+\varepsilon}\right)^{\frac{1}{\eta}}+w^{\frac{\eta-1}{\eta}} \varphi_{2}^{\frac{1}{\eta}}\right) \\
\left.+\frac{\pi \varphi_{1}^{\frac{1}{\eta}}}{\eta}\left(r^{*}+\varepsilon\right)^{\frac{-1-\eta}{\eta}}\left(r^{*} b_{0}+w\right)\right] \\
\left(1+\pi\left(\frac{\varphi_{1}}{r^{*}+\varepsilon}\right)^{\frac{1}{\eta}}+w^{\frac{\eta-1}{\eta}} \varphi_{2}^{\frac{1}{\eta}}\right)^{2}
\end{array}\right) \\
& \left.+\frac{1-\eta}{\eta}\left(\frac{\varphi_{2}}{A^{1-\eta}}\right)^{\frac{1}{\eta}}\left(\frac{r^{*} b_{0}+A}{1+\pi\left(\frac{\varphi_{1}}{r^{*}+\varepsilon}\right)^{\frac{1}{\eta}}+A^{\frac{\eta-1}{\eta}} \varphi_{2}^{\frac{1}{\eta}}}\right)^{\frac{1-2 \eta}{\eta}}\left(\frac{b_{0}\left(1+\pi\left(\frac{\varphi_{1}}{r^{*}+\varepsilon}\right)^{\frac{1}{\eta}}+A^{\frac{\eta-1}{\eta}} \varphi_{2}^{\frac{1}{\eta}}\right)+\frac{\pi \varphi_{1}^{\frac{1}{\eta}}}{\eta}\left(r^{*}+\varepsilon\right)^{\frac{-1-\eta}{\eta}}\left(r^{*} b_{0}+A\right)}{\left(1+\pi\left(\frac{\varphi_{1}}{r^{*}+\varepsilon}\right)^{\frac{1}{\eta}}+A^{\frac{\eta-1}{\eta}} \varphi_{2}^{\frac{1}{\eta}}\right)^{2}}\right)\right]
\end{aligned}
$$


Appendix B. Partial derivative of $W$ with respect to $\varepsilon$

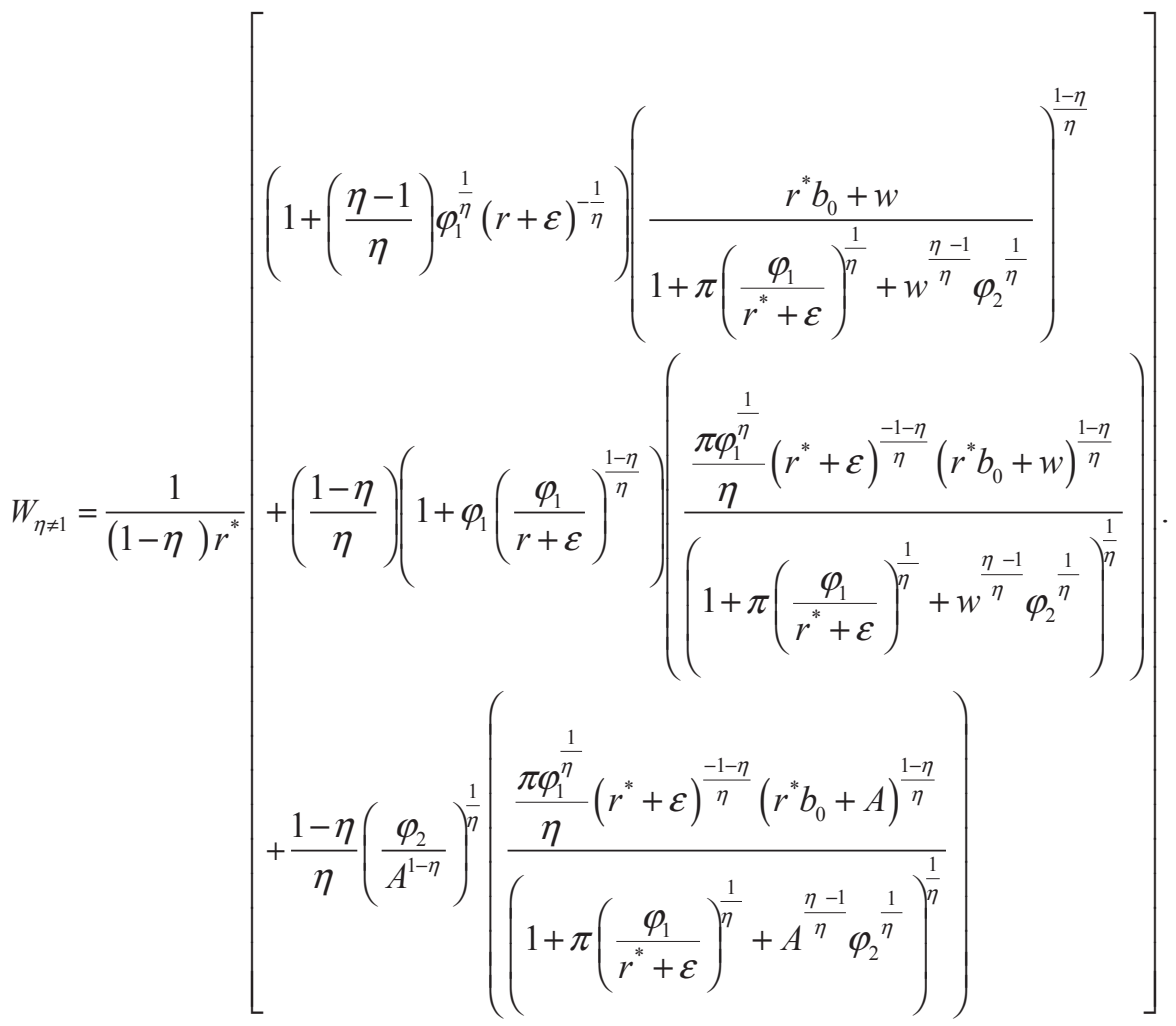

